\title{
37. DEPOSITIONAL AND DIAGENETIC BEHAVIOR OF BARIUM IN THE JAPAN SEA ${ }^{1}$
}

\author{
M. T. von Breymann, ${ }^{2}$ H. Brumsack, ${ }^{3}$ and K. C. Emeis $^{4}$
}

\begin{abstract}
The barium distribution in sediments and pore fluids from five sites drilled in the Japan Sea have been used to illustrate the geochemical behavior of this element as it pertains paleoproductivity reconstructions, diagenetic remobilization, and barite precipitation in authigenic fronts.

Sites where sulfate is depleted in the pore fluids also show high concentrations of dissolved barium, reflecting dissolution of biogenic barite. The high rate of sedimentation at Sites 798 and 799 results in a rapid sulfate depletion, which in turn leads to barite dissolution and reprecipitation in diagenetic fronts. The dissolved barium distribution at these sites has been used to quantify the rate of barite dissolution; we estimate a first-order rate constant for barite dissolution to be $2 \times 10^{-6} / \mathrm{s}$ at Site 799 and $2 \times$ $10^{-7} / \mathrm{s}$ at Site 798.

Authigenic barite has been documented in sediments from Site 799 at 323 meters below seafloor by scanning electron microscopy and X-ray fluorescence analysis. These results indicate barite precipitation in a diagenetic front near the zone of sulfate depletion by upward migration of dissolved barium and downward diffusion of sulfate. Barite precipitation has also been inferred at Sites 796 and 798 based on sedimentary and dissolved barium distributions.

Sulfate is not depleted in the pore fluids of Site 794. The lack of diagenetic remobilization of biogenic barium at this site preserves the high barium signal associated with the high-productivity sequences deposited during the late Miocene to Pliocene. Significantly, the organic carbon distribution does not indicate high accumulation rates during the periods of high opal and barium deposition. Instead, higher organic carbon accumulations are recorded in the Quaternary and middle Miocene sequences; intervals that are also characterized by deposition of siliciclastic turbidites. The presence of a terrestrial component in the organic carbon record renders barium a more useful indicator than organic carbon for paleoproductivity reconstructions in this marginal sea.
\end{abstract}

\section{INTRODUCTION}

\section{Geologic and Oceanographic Setting}

The Japan Sea is a large backarc basin with water depths in excess of $3500 \mathrm{~m}$, separated from the Pacific Ocean by shallow bathymetric sills of less than $150 \mathrm{~m}$ below sea level (mbsl). The objective of drilling in the Japan Sea during Legs 127 and 128 of the Ocean Drilling Program (ODP) was to determine the style and dynamics of marginal sea formation and the parallel oceanographic evolution of the sea (Fig. 1). Table 1 summarizes the location, water depth, and average sedimentation rates at the sites used in this study. Figure 2 illustrates the changes in sedimentation rate with depth a these sites.

The sedimentary sequences overlying basement rocks in the Japan Sea show distinct regional similarities that record the major tectonic and paleoceanographic changes during the evolution of the basin (Fig. 3; Tamaki, Pisciotto, Allan, et al., 1990; Ingle, Suyehiro, von Breymann, et al., 1990). Delta-front sands and siltstones rich in plant debris were deposited during the initial backarc rifting and basin subsidence in the early Miocene. Basin subsidence accelerated during the middle to late Miocene accompanied by widespread deposition of diatomaceous muds at bathyal depths. These deposits reflect increasing rates of primary productivity in the Japan Sea, which probably resulted from climatic cooling and a decrease in the flux of terrigenous sediments to the deepening basinal areas. The diatom flux to the sediments decreased during the Pleistocene, indicating lower productivity in the surface waters concurrent with a major progradation of submarine fans and deposition of coarse siliciclastic sequences.

\footnotetext{
Pisciotto, K. A., Ingle, J. C., Jr., von Breymann, M. T., Barron, J., et al., 1992. Proc, ODP, Sci. Results, 127/128, Pt. 1: College Station, TX (Ocean Drilling Program).

${ }^{2}$ Ocean Drilling Program, Texas A\&M University, 1000 Discovery Drive, College Station, TX 77845-9547, U.S.A. (Present address: GEOMAR, 1-3 Wischhofstrasse, D-2300 Kiel, Federal Republic of Germany.)

${ }^{3}$ Geochemisches Institut, Goldschmidtstrasse 1, D-3400 Goettingen, Federal Republic of Germany.

${ }^{4}$ Geologisch-Paläontologisches Institut, Universităt Kiel, Olshausenstrasse 40/60, D-2300 Kiel, Federal Republic of Germany.
}

Lower productivity during this period probably reflects changes in the oceanographic regime of the basin. The topographic isolation and severe winter climate of the modern Japan Sea leads to the formation of cold low-salinity water in its northern reaches. This high-density water, termed the Liman current, sinks as it travels southward and creates a convection system that maintains a cold, homogeneous, and well-oxygenated water mass at all depths below 300 m (Ingle, 1975a; Worthington, 1981).

Lithofacies recovered during drilling correspond to lithological and faunal sequences onshore (Ingle, 1975b; lijima et al., 1988, Takayasu and Matoba, 1976; Ikebe and Maiya, 1981). All observations demonstrate that the Japan Sea experienced wide extremes of temperature, productivity, and circulation since the time of its formation. The sites drilled in this marginal sea offer a good opportunity to study paleoproductivity variations that result from tectonically and eustatically controlled changes in basin geometry and gateways, as well as from changes in global and local climatic patterns (e.g., Matoba, 1984). The problem of estimating paleoproduction from classical biogenic indicators (organic matter, opal, and calcium carbonate) is that the bottom-arriving flux of these components is highly dependent on water column characteristics. These indicators are strongly affected by degradation in the water column, at the sediment water interface and by sediment diagenesis. For this reason, current research has placed importance on establishing and calibrating new productivity indicators (Jumars et al., 1989) in the hope that these parameters will provide the much needed support for accurate estimates of paleocycling of organic carbon and silica.

\section{Barium as an Indicator of Paleoproductivity}

Particle fluxes of barium and organic carbon in sediment-trap samples are being explored as means to establish a link between primary productivity and the barium flux to the ocean floor (Dymond et al., in press). Sediment-trap data support inferences of a biogenic source for this element based on barium enrichment in sediments underlying the equatorial divergence in the Pacific and Indian oceans (Goldberg and Arrhenius, 1958; Gurvich et al., 1978). Scientific effort 




Figure 1. Map of the Japan Sea showing locations of sites from Ocean Drilling Program Leg 127 (dots) and Leg 128 (circled dots), and Deep Sea Drilling Project Leg 31 (squares). Site 794 was occupied on both Legs 127 and 128. Bathymetry in meters.

has recently been directed toward the use of barium for paleoproductivity reconstructions. For example, Schmitz (1987) used the distribution of nonclastic barium in sediments from the Indian Ocean to trace the northward movement of the Indian plate across the high-productivity equatorial divergence zone. Also, Shimmield and Mowbray (1991) and Weedon and Shimmield (1991) have shown an enhanced increase in sedimentary concentrations of biogenic barium during interglacial productivity maxima in sediments from the Owen Ridge beneath the zone of monsoonal upwelling in the Arabian Sea. These observations are taken as an indication of enhanced ocean fertility associated with strong monsoon circulation during interglacial episodes.

There is still no consensus as to the mode of barium enrichment in conjunction with primary productivity. Barite crystals do not appear to be actively secreted by planktonic organisms. Instead, a syngenetic origin during aggregation, settling, and decay of siliceous matter has been shown in suspended barium (Bishop, 1988) and sediment-trap samples (Dymond et al., in press). The systematic decrease in the organic carbon to barium ratio of organic debris with increasing water depth observed in sediment traps is thought to be a consequence of the simultaneous uptake of barium with the decompositional loss of organic matter. This phenomenon is reflected in barium distributions of sediments from a variety of upwelling and non-upwelling areas (von Breymann et al., in press).

The enrichment of barium during transport through the water column constitutes an advantage for the reconstruction of paleoproductivity in deep-sea environments. Paleoproductivity in these areas is difficult to assess with conventional biogenic indicators because great water depths result in significant losses of these tracers during transit from the sea surface to the sediments. The advantage in using barium accumulation for estimating ocean fertility is the fact that it is significantly less labile than organic matter, opal, and calcium carbonate. Comparison between the rain rates of particulate barium to the seafloor with burial rates indicate that between $30 \%$ and $60 \%$ of the barium is preserved, depending on the sediment mass accumulation rate (MAR) (Dymond et al., in press).

On the other hand, diagenetic redistribution of barium in anoxic systems presents a problem for the application of this element to estimates of biogenic flux. Dissolved barium distributions in pore fluids of the Peru margin (von Breymann et al., 1990b) and Gulf of California (Brumsack, 1986) sediments indicate barite dissolution in intervals depleted in interstitial sulfate. Upward diffusion of dissolved barium results in local barite precipitation in sediments near the termination of the sulfate-reducing zone.

In this study we have examined the barium record in Japan Sea sediments to evaluate the deposition of biogenic barium in relation to productivity changes. Sites where sulfate is exhausted in the sediments have been used to quantify the rate of dissolution of barite, and its reprecipitation in diagenetic fronts.

\section{METHODS}

Sediment samples were obtained aboard the JOIDES Resolution, freeze-dried, and ground. The organic carbon content of the sediments was determined aboard ship by a Carlo Erba elemental analyzer (Tamaki, Pisciotto, Allan, et al., 1990; Ingle, Suyehiro, von Breymann, et al., 1990). Barium and aluminum concentrations were measured in samples from Sites 794, 796, 798, and 799 by neutron activation analysis (INAA) at the Texas A\&M University Nuclear 
Table 1. Location, water depth, and average sedimentation rates for ODP sites in the Japan Sea.

\begin{tabular}{cccccl}
\hline Site & $\begin{array}{c}\text { Latitude } \\
(\mathrm{N})\end{array}$ & $\begin{array}{c}\text { Longitude } \\
(\mathrm{E})\end{array}$ & $\begin{array}{c}\text { Water depth } \\
(\mathrm{m})\end{array}$ & $\begin{array}{c}\text { Sedimentation rate } \\
(\mathrm{m} / \mathrm{m} . \mathrm{y} .)\end{array}$ & Location \\
\hline 794 & $40^{\circ} 11.4^{\prime}$ & $138^{\circ} 13.9^{\prime}$ & 2850 & 35 & Yamato Basin \\
795 & $43^{\circ} 59.2^{\prime}$ & $138^{\circ} 58.0^{\prime}$ & 3300 & 50 & Japan Basin \\
796 & $42^{\circ} 50.9^{\prime}$ & $139^{\circ} 24.7^{\prime}$ & 2571 & 40 & Japan Basin \\
798 & $37^{\circ} 02.3^{\prime}$ & $134^{\circ} 48.0^{\prime}$ & 903 & 120 & Oki Ridge \\
799 & $39^{\circ} 13.2^{\prime}$ & $133^{\circ} 52.0^{\prime}$ & 2084 & 127 & Kita-Yamato Trough \\
\hline
\end{tabular}

Note: Data from Tamaki, Pisciotto, Allan, et al. (1990) and Ingle, Suyehiro, von Breymann, et al. (1990).

Science Center. The counting was performed using a germanium-lithium gamma-detector, coupled with a pulse-height multichannel analyzer. The precision of the analysis is better than $5 \%$. A barite layer at Site 799 was identified by scanning electron microscopy (SEM) and $\mathrm{X}$-ray fluorescence (XRF) analysis performed at the University d'Orleans, France.

Interstitial fluids were collected by pressure filtration. The sample handling and analytical techniques used are those described in Gieskes and Peretsman (1986). Sulfate was measured aboard ship by ion chromatography using a $0.25: 50$ dilution of the sample with nanopure water. Barium was determined in the pore waters by ICPAES on 1:10 or 1:100 dilutions of the pore water with deionized water. Calibration solutions were made by spiking a $3 \% \mathrm{NaCl}$ solution (sulfate-free) with the appropriate amounts of barium. The accuracy was tested by analyzing acid digestions of international standard rocks; precision of the method is better than $5 \%$.

\section{RESULTS AND DISCUSSION}

Barium and aluminum concentrations in sediments from Sites $794,796,798$, and 799 are given in Table 2. The downcore distributions of these elements and organic carbon are illustrated in Figure 4. Results from the analysis of dissolved sulfate and barium in the interstitial fluids are shown in Table 3 and Figure 5.

\section{Barium as a Recorder of Productivity in the Japan Sea: Site 794}

In pelagic environments particulate barium fluxes are usually dominated by biogenic sources, although detrital aluminosilicates and hydrothermal processes may also constitute a source for this element in marine sediments (Dymond, 1981; Dymond et al., in press). In the Japan Sea nonmarine volcaniclastic and hydrothermal deposits are common only for the period following its initial rift (early Miocene). Barium minerals of volcanic and hydrothermal origin have been observed in these sequences (Pouclet et al., this volume). We have therefore restricted our study to sediments younger than the middle Miocene, a sequence that is mostly composed of terrigenous and biogenic constituents (Ingle, Suyehiro, von Breymann, et al., 1990; Tamaki, Pisciotto, Allan, et al., 1990). By considering only sediments with a detrital or biogenic barium source, we can use a simple normative correction for the detrital fraction; an approach that has been successfully used for a variety of areas and sediment types (Dymond, 1981; Leinen and Pisias, 1984, Dymond et al., 1984). In this manner, the biogenic fraction $\left(\mathrm{Ba}_{\text {bio }}\right)$ may be estimated by

$$
\mathrm{Ba}_{\text {bio }}=\mathrm{Ba}_{\text {total }}-\left(\mathrm{Al}_{\text {total }} \times \mathrm{Ba} / \mathrm{Al}_{\text {detrital }}\right) \text {. }
$$

This approximation assumes that all the aluminum is of detrital origin. As suggested by Dymond et al. (in press), we have utilized a barium to aluminum ratio of the detrital particles of 0.0075 . This average value was calculated using various compilations of elemental abundances in crustal rocks (Taylor, 1964; Rösler and Lange, 1972). Results from barium and aluminum fluxes in settling particles indicate that variations from the

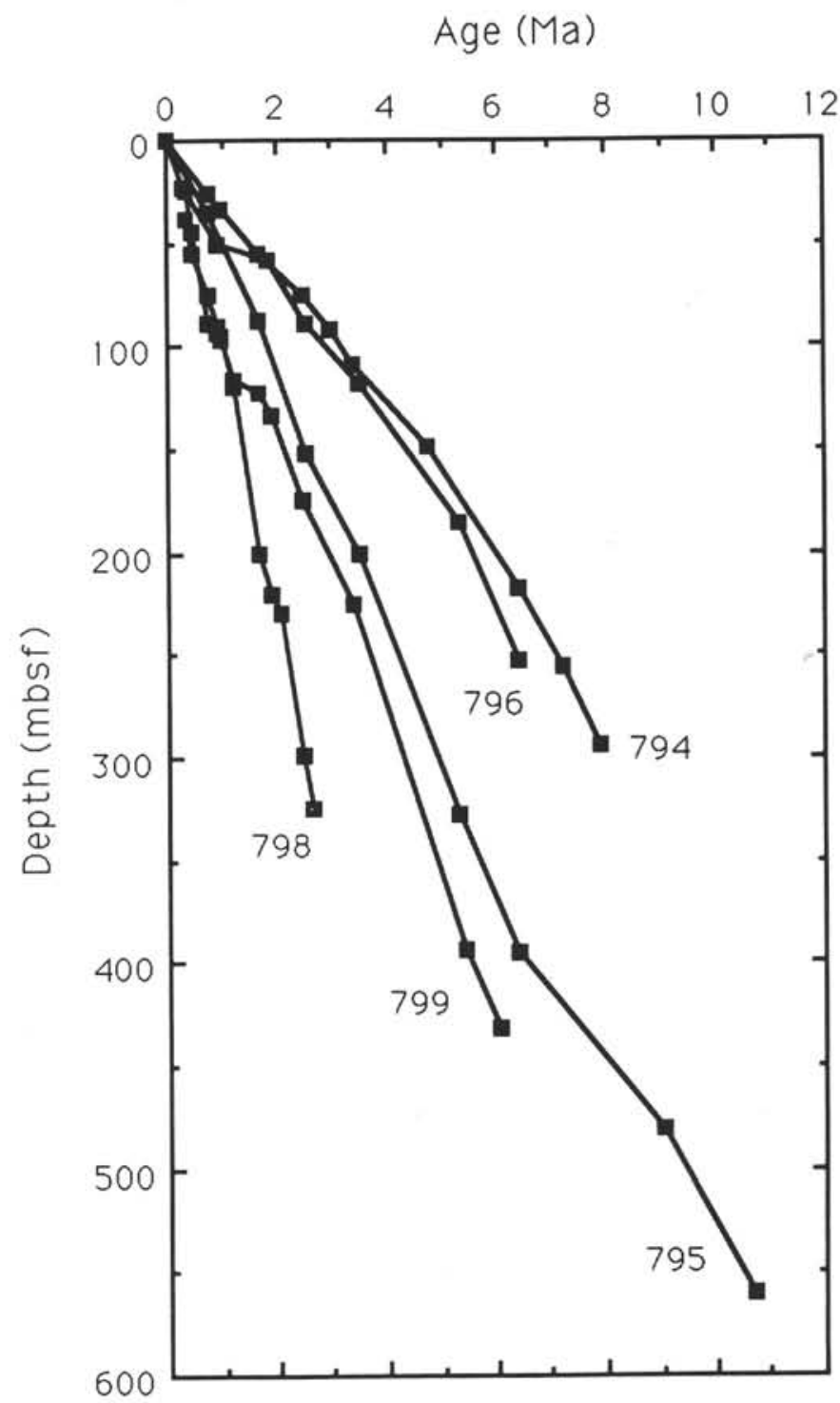

Figure 2. Age vs. depth relationships from the late Miocene to the present at the Japan Sea drill sites used in this study. Data from Tamaki, Pisciotto, Allan, et al. (1990) and Ingle, Suyehiro, von Breymann, et al. (1990).

0.0075 value will introduce a $15 \%$ error in samples with $30 \%$ detrital barium, and thus equation 1 can predict the biogenic fraction with sufficient accuracy in locations where the detrital contribution is less than $30 \%$ of the total rain (Dymond et al., in press). Figure 6 shows the result of this calculation at Site 794, which indicates that during the late Miocene high-productivity intervals the detrital fraction is indeed less than $30 \%$ of the total barium content.

We have compared the organic carbon to biogenic barium in the Japan Sea sediments with those expected from the organic carbon and barium fluxes observed in other parts of the ocean. Dymond et al. (in press) have shown that systematic variations of the $\mathrm{C}_{\text {org }} / \mathrm{Ba}$ ratio in the particle rain can be estimated as a function of water depth, and that site-to-site changes in the decrease rate of the $\mathrm{C}_{\mathrm{org}} / \mathrm{Ba}$ values with depth seem to be related to the dissolved barium content of deep water. We have selected their relationship for the Equatorial Pacific and the present water depth of the Japan Sea sites to estimate the organic carbon to barium rain ratio in the Japan Sea from the late Miocene to the present. The Equatorial Pacific data was selected because the estimated deep-water barium content at this location $(110 \mu \mathrm{m} / \mathrm{kg}$, 
Table 2. Concentration of barium and aluminum in sediments from Sites 794, 796, 798, and 799.

\begin{tabular}{llcc}
\hline $\begin{array}{l}\text { Core, section, } \\
\text { interval (cm) }\end{array}$ & $\begin{array}{c}\text { Depth } \\
\text { (mbsf) }\end{array}$ & $\begin{array}{c}\text { Al } \\
(\%)\end{array}$ & $\begin{array}{c}\mathrm{Ba} \\
(\mathrm{ppm})\end{array}$ \\
\hline
\end{tabular}

$$
\text { 127-794A- }
$$

$\begin{array}{lrrr}1 \mathrm{H}-2,100-102 & 2.50 & 8.07 & 720 \\ 2 \mathrm{H}-3,100-102 & 10.80 & 8.04 & 980 \\ 4 \mathrm{H}-5,100-101 & 32.80 & 8.61 & 840 \\ 5 \mathrm{H}-5,100-101 & 42.30 & 7.96 & 1260 \\ 7 \mathrm{H}-2,100-102 & 56.80 & 9.10 & 950 \\ 9 \mathrm{H}-2,101-102 & 75.81 & 7.07 & 940 \\ 12 \mathrm{H}-2,100-102 & 104.30 & 6.97 & 1470 \\ 15 \mathrm{H}-2,100-101 & 132.80 & 3.94 & 3060 \\ 17 \mathrm{X}-5,100-101 & 156.50 & 5.46 & 2320 \\ 19 \mathrm{X}-5,100-101 & 175.50 & 5.79 & 3030 \\ 21 \mathrm{X}-5,80-82 & 194.70 & 4.26 & 2500 \\ 23 \mathrm{X}-5,100-102 & 214.20 & 4.68 & 1930 \\ 26 \mathrm{X}-5,100-102 & 243.20 & 3.63 & 1220 \\ 30 \mathrm{X}-2,100-102 & 277.60 & 5.63 & 3110 \\ 35 \mathrm{X}-2,100-101 & 324.70 & 7.59 & 1410 \\ 9 \mathrm{R}-1,57-58 & 376.57 & 2.94 & 1480 \\ 13 \mathrm{R}-1,118-120 & 415.68 & 4.24 & 980 \\ 16 \mathrm{R}-1,64-66 & 443.84 & 3.63 & 1390 \\ 20 \mathrm{R}-1,44-46 & 482.44 & 3.71 & 2540 \\ 24 \mathrm{R}-3,70-72 & 524.30 & 7.24 & 740\end{array}$

127-796A-

$\begin{array}{lrrr}1 \mathrm{H}-1,58-61 & 0.58 & 8.45 & 520 \\ 1 \mathrm{H}-1,64-67 & 0.64 & 7.58 & 860 \\ 1 \mathrm{H}-2,40-42 & 1.90 & 7.57 & 900 \\ 1 \mathrm{H}-3,0-5 & 2.10 & 7.44 & 860 \\ 2 \mathrm{H}-5,0-5 & 9.20 & 7.71 & 2680 \\ 3 \mathrm{H}-2,80-81 & 15.00 & 6.74 & 1250 \\ 4 \mathrm{H}-5,109-111 & 29.29 & 7.85 & 1960 \\ 8 \mathrm{H}-5,49-50 & 58.19 & 7.70 & 1160 \\ 12 \mathrm{X}-5,80-82 & 91.90 & 5.57 & 440 \\ 18 \mathrm{X}-2,99-101 & 148.69 & 6.12 & 315 \\ 19 \mathrm{X}-2,99-101 & 158.29 & 4.38 & 270 \\ 22 \mathrm{X}-2,98-101 & 187.18 & 7.70 & 540 \\ 26 \mathrm{X}-2,87-88 & 225.87 & 6.34 & 270 \\ 15 \mathrm{R}-2,83-85 & 293.63 & 5.82 & 240 \\ 20 \mathrm{R}-1,114-116 & 340.94 & 3.83 & 500\end{array}$

128-798B-
Table 2 (continued).

\begin{tabular}{|c|c|c|c|}
\hline $\begin{array}{l}\text { Core, section, } \\
\text { interval }(\mathrm{cm})\end{array}$ & $\begin{array}{l}\text { Depth } \\
\text { (mbsf) }\end{array}$ & $\begin{array}{c}\mathrm{Al} \\
(\%)\end{array}$ & $\begin{array}{c}\mathrm{Ba} \\
\text { (ppm) }\end{array}$ \\
\hline $2 \mathrm{H}-4,4-9$ & 13.84 & 7.83 & 630 \\
\hline $4 \mathrm{H}-4,59-61$ & 32.39 & 7.93 & 1064 \\
\hline $6 \mathrm{H}-4,4-9$ & 50.74 & 6.08 & 622 \\
\hline $7 \mathrm{H}-4,50-55$ & 60.36 & 7.93 & 687 \\
\hline $13 \mathrm{H}-4,74-79$ & 118.63 & 6.63 & 749 \\
\hline $14 \mathrm{H}-4,62-67$ & 127.12 & 7.00 & 834 \\
\hline $17 X-4,28-35$ & 156.19 & 4.43 & 666 \\
\hline $22 X-4,17-22$ & 205.27 & 5.03 & 846 \\
\hline $27 X-4,15-20$ & 253.65 & 6.09 & 1064 \\
\hline $32 X-4,70-75$ & 301.2 & 4.52 & 773 \\
\hline $38 \mathrm{X}-4,31-33$ & 358.71 & 6.77 & 882 \\
\hline $43 \times-4,50-55$ & 407.21 & 10.00 & 1085 \\
\hline $49 X-4,112-114$ & 465.69 & 8.36 & 958 \\
\hline $53 X-4,95-97$ & 504.15 & 7.47 & 12852 \\
\hline $7 R-1,58-60$ & 407.38 & 6.49 & 2440 \\
\hline \multicolumn{4}{|l|}{ 128-799B- } \\
\hline $1 \mathrm{H}-1,44-49$ & 0.44 & 5.73 & 943 \\
\hline $2 \mathrm{H}-4,74-78$ & 6.44 & 7.42 & 850 \\
\hline $3 \mathrm{H}-2,10-15$ & 12.30 & 6.46 & 1091 \\
\hline $4 \mathrm{H}-2,20-25$ & 22.00 & 7.66 & 708 \\
\hline $5 \mathrm{H}-2,20-25$ & 31.60 & 7.93 & 946 \\
\hline $6 \mathrm{H}-2,20-25$ & 41.20 & 4.59 & 1098 \\
\hline $7 \mathrm{H}-2,40-44$ & 51.00 & 7.44 & 1094 \\
\hline $8 \mathrm{H}-2,70-74$ & 60.90 & 5.17 & 903 \\
\hline $9 \mathrm{H}-2,30-35$ & 70.10 & 4.19 & 1126 \\
\hline $10 \mathrm{H}-2,25-30$ & 79.65 & 7.20 & 1155 \\
\hline $11 \mathrm{H}-2,20-25$ & 89.20 & 7.16 & 2216 \\
\hline $12 \mathrm{H}-2,20-25$ & 98.90 & 7.01 & 1728 \\
\hline $13 \mathrm{H}-2,26-31$ & 108.56 & 7.18 & 1174 \\
\hline $14 \mathrm{H}-6,30-35$ & 124.30 & 7.54 & 1592 \\
\hline $16 \mathrm{H}-2,60-65$ & 137.90 & 7.75 & 1485 \\
\hline $17 \mathrm{H}-4,40-45$ & 150.40 & 3.97 & 5117 \\
\hline $18 \mathrm{H}-6,40-45$ & 163.10 & 3.51 & 2047 \\
\hline $20 \mathrm{H}-4,20-25$ & 179.20 & 7.00 & 4193 \\
\hline $22 X-6,34-38$ & 201.64 & 3.10 & 4115 \\
\hline $29 X-2,25-30$ & 252.65 & 2.99 & 2887 \\
\hline $35 X-2,66-70$ & 309.46 & 2.66 & 1846 \\
\hline $39 X-4,40-44$ & 350.80 & 3.62 & 2482 \\
\hline $45 \times-4,44-49$ & 405.84 & 2.12 & 2716 \\
\hline $50 X-2,88-92$ & 454.68 & 5.86 & 2261 \\
\hline
\end{tabular}

waters (Fig. 5) and, therefore, we constrained the paleoproductivity reconstructions to this site.

Site 794 lies along the eastern margin of the Japan Sea on a gentle, north-dipping slope that forms the northeastern margin of the Yamato Basin (Fig. 1). Figure 8 shows the accumulation of biogenic barium and organic carbon as a function of depth. The lithologic column also included in this figure clearly shows an increase in diatomaceous components during the high-productivity interval from 100 to $400 \mathrm{~m}$ below seafloor (mbsf). The barium signal is enhanced relative to carbon at the bathyal depths of Site 794. More significantly, the organic carbon distribution does not indicate high accumulation rates during periods of high opal and barium deposition. Instead, higher organic carbon accumulations are recorded in the Quaternary and middle Miocene sequences (Fig. 8). The middle Miocene period is characterized by hemipelagic claystones, gravity-flow tuffs, and minor glauconite deposited at upper bathyal depths. During the late Pliocene to Holocene period, when diatomaceous sedimentation stopped, the propagation of submarine fans led to the accumulation of massive and laminated hemipelagic sediments (Tamaki, Pisciotto, Allan, et al., 1990). This association suggests an allochthonous source for the organic-rich deposits during these periods, reflecting sediment transport from shelf or terrestrial sources. A high terrestrial component above 100 and below 400 mbsf was inferred by shipboard organic geochemists based on elemental and Rock-Eval analysis of sediments at this site (Tamaki, Pisciotto, Allan, et al., 1990).

The presence of a terrestrial signal is a well known problem in assessing paleoproductivity from the organic carbon record. Based on 


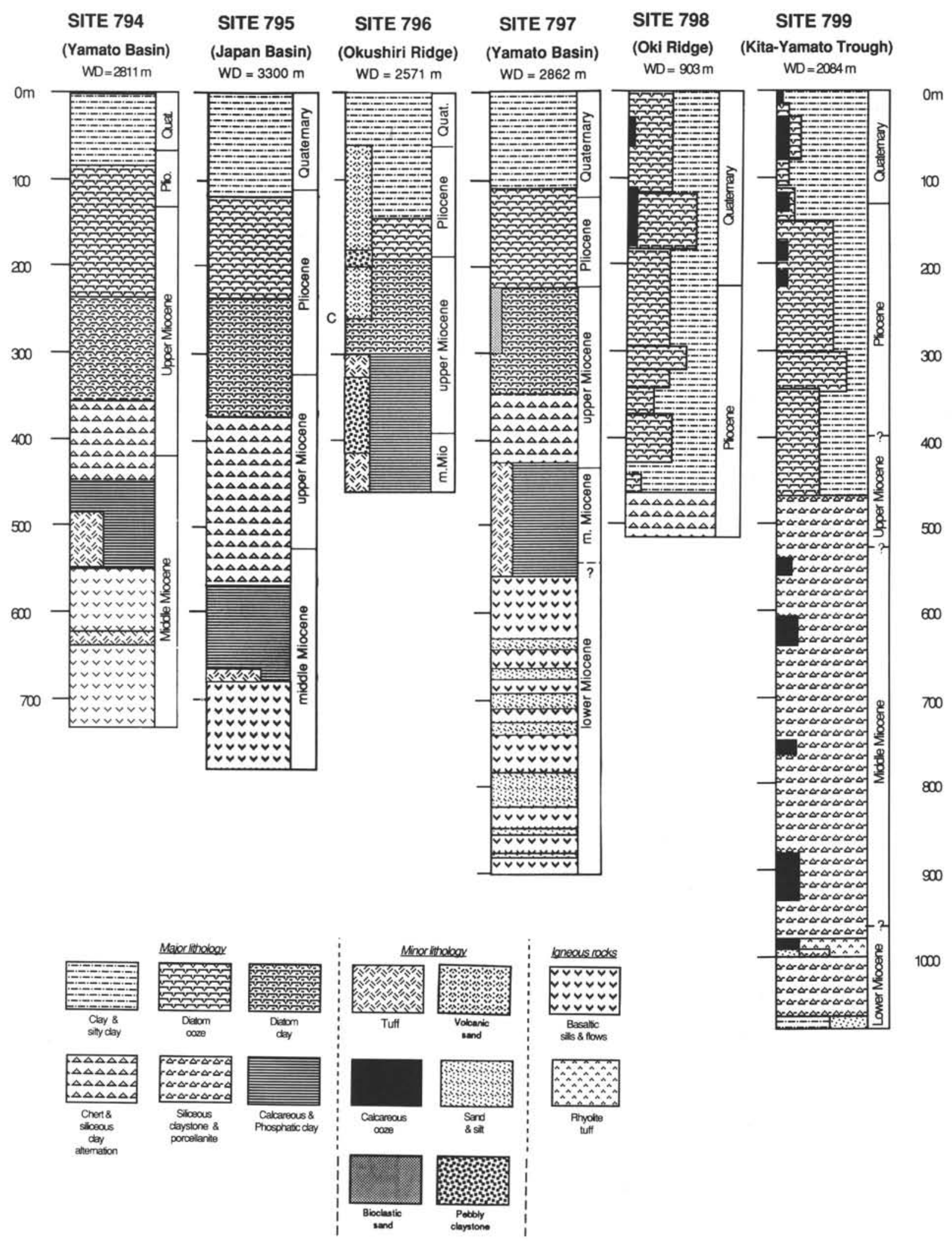

Figure 3. Summary stratigraphic columns for the Japan Sea sites drilled during Legs 127 and 128. WD = water depth. Modified from Tamaki, Pisciotto, Allan, et al. (1990) and Ingle, Suyehiro, von Breymann, et al. (1990). 

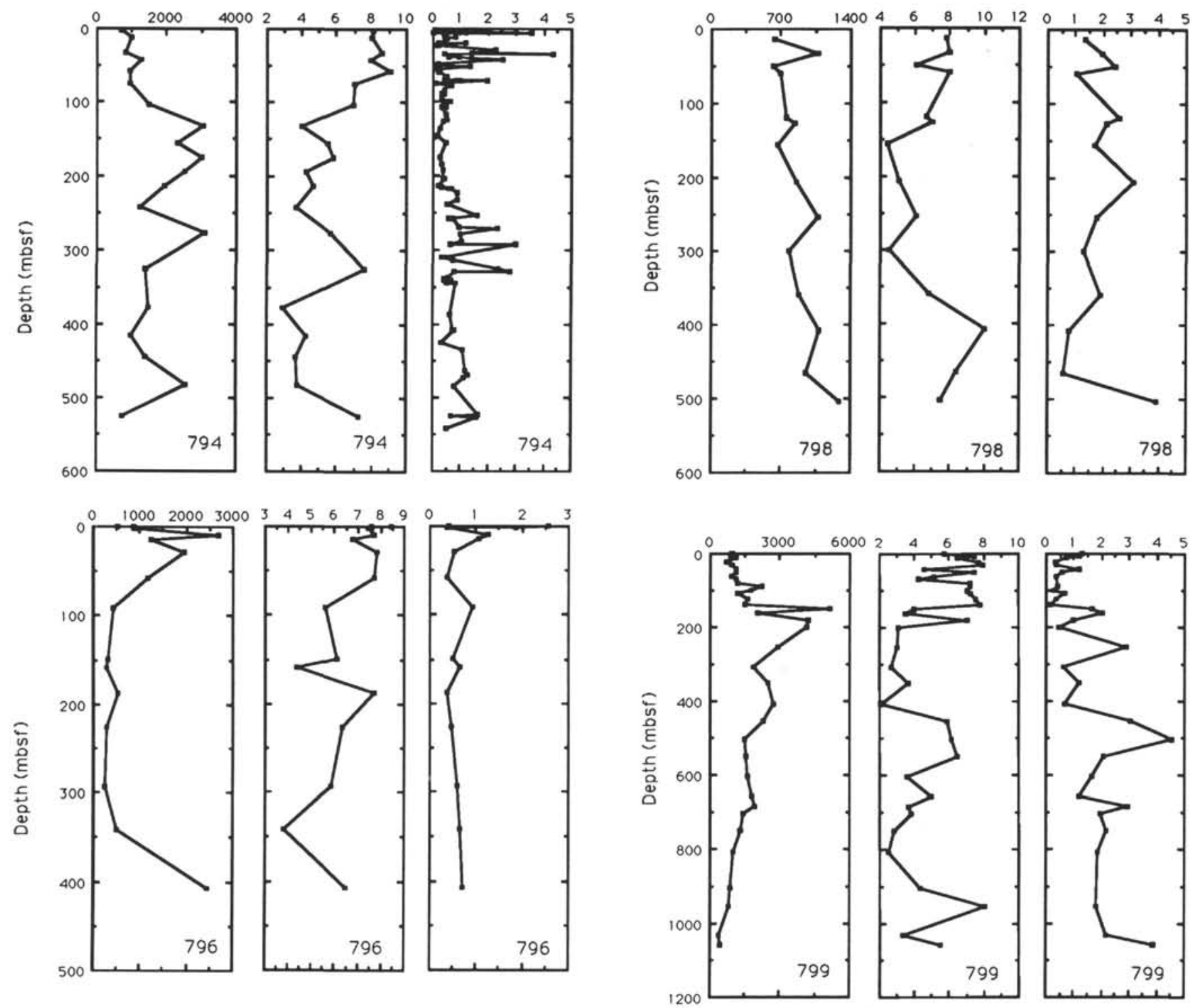

Figure 4. Downcore distribution of barium, aluminum, and organic carbon in the sediments from Sites 794, 796, 798, and 799.

the distribution of biomarkers, Prahl and Muehlhausen (1989) have suggested that marine sediments contain more than $20 \%$ land-derived organic carbon, even in sediments distant from land. Organic-rich turbidite sequences reflecting redeposition of land-or shelf-derived organic carbon have been identified in a wide range of marine settings (e.g. Adams, 1990; Prahl and Muehlhausen, 1989). The large input of nonpelagic organic carbon associated with these deposits significantly affect the paleoproductivity estimates because they do not reflect changes in ocean fertility of the overlying waters. The low-reaction kinetics of the terrestrial material further hinder paleoproductivity estimates based exclusively on the organic carbon distribution. Site 794 provides an example of a system where the barium distribution constitutes a significantly better proxy indicator for paleoproductivity reconstructions than organic carbon.

\section{Diagenetic Remobilization of Barium: Sites 798 and 799}

The high barium concentrations in the interstitial waters of all sites except Site 794 reflect dissolution of some of the biogenic barite under conditions of sulfate depletion (Fig. 5). Dissolved interstitial sulfate gradients are plotted as a function of the bulk sedimentation rates in Figure 9. This empirical relationship, described by Berner (1980), results from the interaction of sulfate diffusion, bacterial sulfate reduction rates, and sediment accumulation rates. These processes have been thoroughly discussed by Murray et al. (this volume) and Craig et al. (this volume). The rate of barium dissolution, however, is not positively correlated with the rate of sulfate consumption (Fig. 9). In order to estimate the dissolution rates at each site, we must concern ourselves with the degree of saturation of the pore fluids with respect to barite because the upward migration of dissolved barium results in the precipitation of particulate barite near the end of the sulfate-reduction zone. The free-ion concentrations of barium and sulfate were estimated using a modified version of MINEQL (Westall et al., 1987), as described by von Breymann et al. (1990a). The ion activity product (IAP) was compared with the barite solubility at $25^{\circ} \mathrm{C}$ and 300 atmospheres $(\mathrm{atm})\left(\mathrm{K}_{\mathrm{d}, 300}=2.3 \times 10^{-10}\right)$. This value was estimated by using the solubility product at $25^{\circ} \mathrm{C}$ and $1 \mathrm{~atm}\left(\mathrm{~K}_{\mathrm{d}, 1}=1.1 \times 10^{-10}\right)$ given by Church and Wolgemuth (1972), a knowledge of the relative 

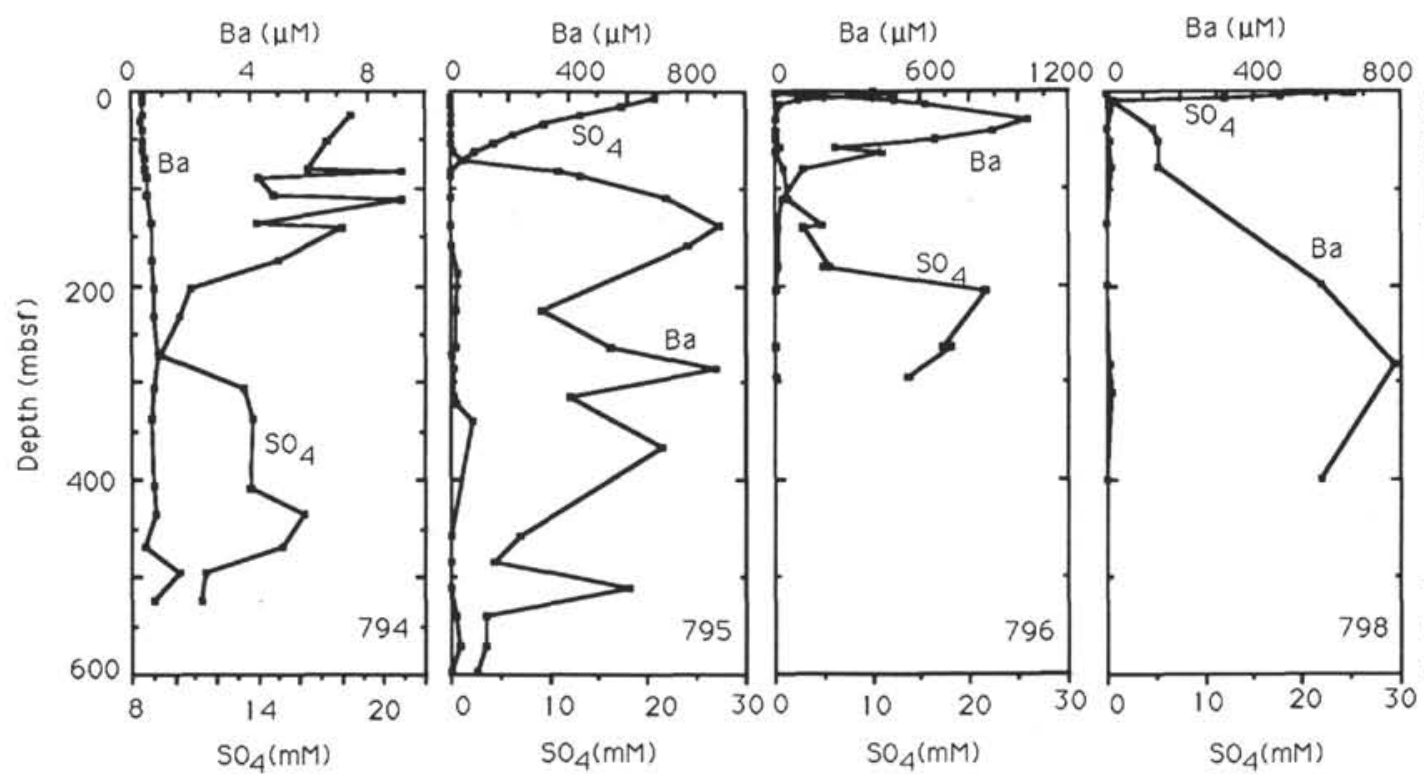

$\mathrm{Ba}(\mu \mathrm{M})$

Figure 5. Downcore distribution of dissolved barium and sulfate in the pore fluids of sites drilled in the Japan Sea. Note the difference in scales. Sulfate data are from Tamaki, Pisciotto, Allan, et al. (1990), and Ingle, Suyehiro, von Breymann, et al. (1990).

A

\section{0}

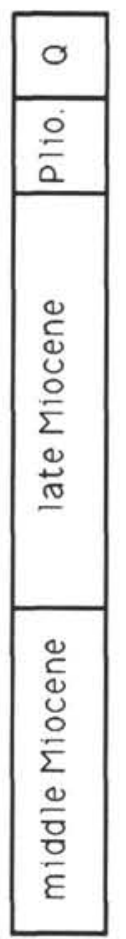

Barium (ppm)



B Barium detrital fraction (\%) 4000

$\begin{array}{llllll}0 & 20 & 40 & 60 & 80 & 100\end{array}$

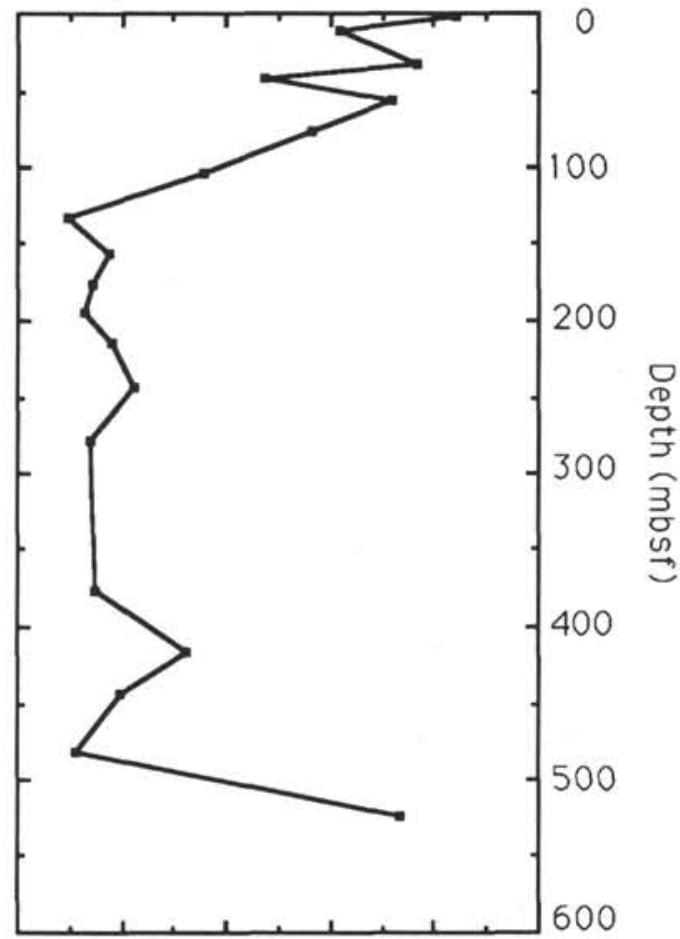

Figure 6. A. Partitioning between detrital (shaded) and biogenic components of the barium content in the sediments at Site 794 vs. depth. B. The detrital fraction expressed as a percentage of the total barium content vs. depth. The detrital fraction was calculated using equation 1 . 
Table 3. Dissolved sulfate and barium concentrations in pore fluids.

\begin{tabular}{cccc}
\hline $\begin{array}{c}\text { Core, section, } \\
\text { interval }(\mathrm{cm})\end{array}$ & $\begin{array}{c}\text { Depth } \\
(\mathrm{mbs})\end{array}$ & $\begin{array}{c}\mathrm{SO}_{4} \\
(\mathrm{mM})\end{array}$ & $\begin{array}{c}\mathrm{Ba} \\
(\mu \mathrm{M})\end{array}$ \\
\hline
\end{tabular}

$127-794 \mathrm{~A}-$

\begin{tabular}{lrrl} 
IH-3, 145-150 & 4.45 & & 0.40 \\
$2 \mathrm{H}-3,145-150$ & 11.25 & & 0.33 \\
$3 \mathrm{H}-5,145-145$ & 23.75 & 18.40 & 0.33 \\
$4 \mathrm{H}-4,145-150$ & 31.75 & & 0.29 \\
$5 \mathrm{H}-4,145-150$ & 41.25 & & 0.33 \\
$6 \mathrm{H}-4,140-145$ & 50.70 & 17.30 & \\
$6 \mathrm{H}-4,145-150$ & 50.75 & & 0.36 \\
$7 \mathrm{H}-4,145-150$ & 60.25 & & 0.36 \\
$8 \mathrm{H}-4,145-150$ & 69.75 & & 0.44 \\
$9 \mathrm{H}-4,140-145$ & 79.20 & 16.40 & 0.47 \\
$10 \mathrm{H}-1,0-10$ & 82.80 & 20.90 & \\
$10 \mathrm{H}-4,145-150$ & 88.75 & 14.00 & 0.51 \\
$12 \mathrm{H}-4,140-145$ & 107.70 & 14.70 & \\
$12 \mathrm{H}-4,145-150$ & 107.75 & & 0.51 \\
$13 \mathrm{H}-1,0-10$ & 111.30 & 20.90 & \\
$15 \mathrm{H}-4,140-145$ & 136.20 & 13.90 & 0.69 \\
$16 \mathrm{X}-1,0-10$ & 139.80 & 18.00 & \\
$19 \mathrm{X}-4,140-145$ & 174.40 & 15.00 & 0.69 \\
$22 \mathrm{X}-4,140-145$ & 203.40 & 10.80 & 0.73 \\
$25 \mathrm{X}-4,140-145$ & 232.40 & 10.20 & 0.73 \\
$29 \mathrm{X}-4,140-145$ & 271.30 & 9.30 & \\
$29 \mathrm{X}-4,145-150$ & 271.35 & & 0.84 \\
$33 \mathrm{X}-2,140-145$ & 306.20 & & 0.73 \\
$33 \mathrm{X}-2,145-150$ & 306.25 & 13.30 & \\
$36 \mathrm{X}-4,140-145$ & 337.80 & 13.70 & \\
$36 \mathrm{X}-4,145-150$ & 337.85 & & 0.69 \\
\hline & & &
\end{tabular}

127-794B-

$12 \mathrm{R}-2,145-150$

$15 \mathrm{R}-1,145-150$

$18 \mathrm{R}-4,145-150$

$21 \mathrm{R}-3,145-150$

$24 \mathrm{R}-2,140-145$

406.35

407.85

435.25

468.55

496.15

523.50

13.60

16.20

15.20

11.50

11.30

0.73

0.80

0.47

1.57

127-795A-

\section{$1 \mathrm{H}-4,145-150$}

$2 \mathrm{H}-4,145-150$

$3 \mathrm{H}-4,145-150$

$4 \mathrm{H}-4,145-150$

$5 \mathrm{H}-4,145-150$

$6 \mathrm{H}-4,145-150$

$7 \mathrm{H}-4,145-150$

$8 \mathrm{H}-4,145-150$

$9 \mathrm{H}-4,145-150$

$10 \mathrm{H}-1,145-150$

$12 \mathrm{H}-4,140-145$

$12 \mathrm{H}-4,145-150$

$15 \mathrm{H}-4,145-150$

$18 \mathrm{H}-4,140-145$

$18 \mathrm{H}-4,145-150$

$21 \mathrm{X}-4,145-150$

$25 \mathrm{X}-3,140-145$

$25 \mathrm{X}-3,145-150$

29X-2, 145-150

$30 \mathrm{X}-2,145-150$

$31 X-4,145-150$

$34 \mathrm{X}-5,145-150$

$35 \mathrm{X}-2,145-150$

37X-1, 138-143

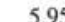

15.25

34.25

43.75

53.25

62.75

72.25

81.75

86.75

110.20

110.25

138.75

158.80

158.85

187.55

224.80

224.85

262.45

272.25

285.05

315.35

320.55

338.28

127-795B-

$1 \mathrm{R}-1,140-145$
$10 \mathrm{R}-4,140-145$
$10 \mathrm{R}-4,145-150$
$13 \mathrm{R}-2,140-145$
$13 \mathrm{R}-2,145-150$
$16 \mathrm{R}-1,145-150$
$19 \mathrm{R}-1,140-145$
$19 \mathrm{R}-1,145-150$

$\begin{array}{lll}366.60 & & 715 \\ 457.90 & & 230 \\ 457.95 & 0.00 & \\ 483.90 & & 145 \\ 483.95 & 0.00 & \\ 511.15 & 0.00 & 605 \\ 540.10 & & 120 \\ 540.15 & 0.40 & \end{array}$

Table 3 (continued).

\begin{tabular}{|c|c|c|c|}
\hline $\begin{array}{l}\text { Core, section, } \\
\text { interval }(\mathrm{cm})\end{array}$ & $\begin{array}{l}\text { Depth } \\
\text { (mbsf) }\end{array}$ & $\begin{array}{c}\mathrm{SO}_{4} \\
(\mathrm{mM})\end{array}$ & $\underset{(\mu \mathrm{M})}{\mathrm{Ba}}$ \\
\hline $22 \mathrm{R}-2,84-89$ & 570.04 & 0.90 & 115 \\
\hline $25 \mathrm{R}-1,140-145$ & 598.10 & & 90.0 \\
\hline $25 \mathrm{R}-1,145-150$ & 598.15 & 0.00 & \\
\hline $28 \mathrm{R}-2,140-145$ & 628.60 & & 56.0 \\
\hline $28 \mathrm{R}-2,145-150$ & 628.65 & 0.00 & \\
\hline $31 \mathrm{R}-5,143-150$ & 661.93 & & 5.9 \\
\hline \multicolumn{4}{|l|}{$127-796 \mathrm{~A}-$} \\
\hline $1 \mathrm{H}-1,50-55$ & 0.50 & 10.10 & \\
\hline $1 \mathrm{H}-2,55-60$ & 2.05 & 9.80 & 1.4 \\
\hline $2 \mathrm{H}-4,145-150$ & 9.15 & 2.30 & 489 \\
\hline $2 \mathrm{H}-4,145-150$ & 9.15 & 2.30 & \\
\hline $3 \mathrm{H}-1,140-145$ & 14.10 & 0.40 & \\
\hline $3 \mathrm{H}-1,145-150$ & 14.15 & 0.40 & 621 \\
\hline $4 \mathrm{H}-5,145-150$ & 29.65 & 0.00 & 1034 \\
\hline $5 \mathrm{H}-5,145-150$ & 39.15 & 0.00 & 896 \\
\hline $6 \mathrm{H}-6,140-145$ & 50.10 & 0.00 & \\
\hline $6 \mathrm{H}-6,145-150$ & 50.15 & 0.00 & 657 \\
\hline $8 \mathrm{H}-5,93-98$ & 58.63 & 0.40 & 241 \\
\hline $9 X-2,140-145$ & 61.60 & 0.00 & 441 \\
\hline $11 X-1,145-150$ & 79.75 & 0.90 & 116 \\
\hline $14 X-2,140-145$ & 110.50 & & 24.3 \\
\hline $14 X-2,140-145$ & 110.50 & 1.30 & \\
\hline $17 X-2,140-145$ & 139.40 & 4.90 & \\
\hline $17 X-2,145-150$ & 139.45 & 2.80 & 6.1 \\
\hline $21 X-4,140-145$ & 180.90 & 5.40 & \\
\hline $21 X-4,145-150$ & 180.95 & 4.80 & 4.4 \\
\hline $24 \mathrm{X}-1,140-145$ & 205.50 & 21.40 & \\
\hline $24 \mathrm{X}-1,145-150$ & 205.55 & 21.70 & 1.0 \\
\hline \multicolumn{4}{|l|}{$127-796 \mathrm{~B}-$} \\
\hline $1 \mathrm{R}-2,145-150$ & 2.95 & 12.10 & 1.3 \\
\hline $12 \mathrm{R}-1,140-145$ & 263.70 & 17.30 & \\
\hline $12 \mathrm{R}-1,145-150$ & 263.75 & 18.20 & 1.2 \\
\hline $15 \mathrm{R}-2,140-145$ & 294.20 & 13.60 & \\
\hline $15 R-2,145-150$ & 294.25 & 13.90 & 1.3 \\
\hline
\end{tabular}

127-797B-




Table 3 (continued).

\begin{tabular}{|c|c|c|c|}
\hline $\begin{array}{l}\text { Core, section, } \\
\text { interval }(\mathrm{cm})\end{array}$ & $\begin{array}{l}\text { Depth } \\
\text { (mbsf) }\end{array}$ & $\underset{(\mathrm{mM})}{\mathrm{SO}_{4}}$ & $\begin{array}{c}\mathrm{Ba} \\
(\mu \mathrm{M})\end{array}$ \\
\hline \multicolumn{4}{|l|}{$127-797 \mathrm{C}$ - } \\
\hline $5 R-2,145-150$ & 524.95 & 9.00 & 0.6 \\
\hline \multicolumn{4}{|l|}{ 128-798B- } \\
\hline $1 \mathrm{H}-1,125-131$ & 1.25 & 25.10 & 0.0 \\
\hline $1 \mathrm{H}-2,35-41$ & 1.85 & 24.40 & \\
\hline IH- $2,127-133$ & 2.77 & 21.50 & \\
\hline $1 \mathrm{H}-3,100-106$ & 4.00 & 17.70 & \\
\hline $1 \mathrm{H}-4,125-131$ & 5.75 & 12.00 & \\
\hline $2 \mathrm{H}-1,45-51$ & 9.85 & 0.60 & 13.1 \\
\hline $2 \mathrm{H}-3,45-51$ & 12.85 & 0.30 & \\
\hline $3 \mathrm{H}-4,85-91$ & 23.75 & 0.10 & \\
\hline $4 \mathrm{H}-7,56-61$ & 36.96 & 0.00 & 121 \\
\hline $5 \mathrm{H}-4,140-150$ & 42.70 & 0.00 & \\
\hline $6 \mathrm{H}-4,45-55$ & 50.59 & 0.30 & 143 \\
\hline $7 \mathrm{H}-3,140-150$ & 59.98 & 0.10 & \\
\hline $9 \mathrm{H}-3,123-133$ & 78.57 & 0.40 & 139 \\
\hline $14 \mathrm{H}-7,123-133$ & 133.13 & 0.00 & \\
\hline $15 \mathrm{H}-5,140-150$ & 140.08 & 0.00 & \\
\hline $21 X-6,140-150$ & 199.21 & 0.00 & 582 \\
\hline $30 \times-2,140-150$ & 280.10 & 0.00 & 785 \\
\hline $42 X-5,140-150$ & 398.85 & 0.00 & 582 \\
\hline \multicolumn{4}{|l|}{$128-799 \mathrm{~A}-$} \\
\hline $2 \mathrm{H}-1,145-150$ & 2.85 & 19.60 & 0.0 \\
\hline $3 \mathrm{H}-4,135-140$ & 16.55 & 2.90 & 5.1 \\
\hline $5 \mathrm{H}-4,140-145$ & 35.85 & 0.00 & 257 \\
\hline $6 \mathrm{H}-3,140-145$ & 43.90 & 0.00 & 347 \\
\hline $9 \mathrm{H}-3,140-145$ & 72.70 & 0.00 & 572 \\
\hline $12 \mathrm{H}-4,140-145$ & 103.10 & 0.10 & 783 \\
\hline $15 \mathrm{H}-4,140-145$ & 132.00 & 0.00 & 1189 \\
\hline $15 \mathrm{H}-4,140-145$ & 132.00 & 0.00 & 1238 \\
\hline $21 X-4,140-145$ & 190.00 & 0.20 & 1387 \\
\hline $33 X-5,140-145$ & 295.30 & 0.20 & 2192 \\
\hline $39 X-3,140-145$ & 350.30 & 0.20 & 1593 \\
\hline $45 X-3,140-145$ & 408.30 & 0.30 & 2311 \\
\hline $48 X-2,140-145$ & 435.80 & 0.20 & 2138 \\
\hline \multicolumn{4}{|l|}{ 128-799B- } \\
\hline $7 \mathrm{R}-2,140-150$ & 502.60 & 0.00 & 807 \\
\hline $12 \mathrm{R}-3,140-150$ & 552.30 & 0.00 & 1275 \\
\hline $16 \mathrm{R}-3,140-150$ & 591.00 & 0.00 & 1273 \\
\hline
\end{tabular}

change of molal volume $\left(-40.6 \mathrm{~cm}^{3} /\right.$ mole), and the formulation of Owen and Brinkley (1941).

Figure 10 illustrates the degree of saturation of the pore fluids with respect to barite. We may assume that the main processes affecting the distributions of dissolved barium in the unsaturated pore fluids are ion diffusion and barite dissolution. With these assumptions we may estimate the rate of dissolution by using the general diagenetic equation (Berner, 1980). We may further assume a first-order reaction, independent of the reactive barium concentration, as a first approximation for the purpose of mathematical modeling. The rate law for barite dissolution should then be of the form

$$
R=k_{m}\left(C_{\infty}-C\right),
$$

where $C=$ concentration of dissolved barium; $C_{\infty}=$ asymptotic concentration attained at infinite depth-it can be but it is not necessarily the dissolved barium at saturation with barite; and $k_{m}=$ rate constant.

The dissolution profiles may be characterized by the standard vertical diffusion model of Berner (1980). Further assuming that (1) there is no barite precipitation above the saturation zone, (2) compac-



Figure 7. Organic carbon vs. biogenic barium. The solid lines represent the $\mathrm{C}_{\mathrm{org}} / \mathrm{Ba}_{\text {bio }}$ burial ratios estimated using the algorithms of Dymond et al. (in press) and Dymond and Lyle (in press). These ratios are a function of water depth; a relationship that is apparent in the difference in $\mathrm{C}_{\text {org }} / \mathrm{Ba}_{\text {bio }}$ between Site 798 ( 973 $\mathrm{mbsl}$ ) and the other sites drilled in water depths greater than $2000 \mathrm{~m}$. Samples that show a high enrichment of barium relative to the burial ratio (Sites 796 and 799) are likely to represent the precipitation of authigenic barite in diagenetic fronts.

tion and water flow are slow compared to pore-water diffusion, and (3) steady state diagenesis, then

$$
D_{s}\left(\partial^{2} C / \partial z^{2}\right)-W(\partial C / \partial z)+k_{m}\left(C_{\infty}-C\right)=0
$$

where $D_{s}=$ whole sediment diffusion coefficient for barium, taken as approximately equal to $8 \times 10^{-6} \mathrm{~cm}^{2} \cdot \mathrm{s}-1$ ( $\mathrm{Li}$ and Gregory, 1974); $z=$ depth, and $W=$ sedimentation rate.

For boundary conditions, we will take for $z=0, C=C_{s w}$ (the barium concentration in seawater), and for $z=\infty, C=C_{\infty}$. Integrating over depth we obtain

$$
C=\left(C_{s w}+C_{\infty}\right) \exp \left[\frac{W+\left(W^{2}+4 k_{m} D_{s}\right)^{1 / 2}}{2 D_{s}}\right] z-C_{\infty} .
$$

Because $C_{\infty} \gg C_{s w}$, and if the reaction rate constant is high relative to the accumulation rate, equation 4 can be simplified to

$$
C=C_{\infty} \exp \left[\left(k_{m} / D_{s}\right)^{1 / 2}\right] z-C_{\infty} .
$$

Only at Sites 798 and 799 the dissolved barium profiles allow us to estimate the value for $\mathrm{C} \infty$. From the best fit of equation 5 to the data (assuming $C_{\infty}=1250 \mu \mathrm{M}$, Fig. 11) we estimate the rate constant for barite dissolution to be $2 \times 10^{-6} / \mathrm{s}$ at Site 799 and $2 \times 10^{-7} / \mathrm{s}$ at Site 798. The difference in the rate constants might be due to site-to-site variations in the kinetics, lack of steady-state conditions or it may indicate that the reaction rate is dependent on the concentration of "reactive" biogenic barite, a value that is approximately 3 times larger at Site 799 than at Site 798 (Fig. 7).

Because the highest reported sedimentation rates at the sites is 120 $\mathrm{m} / \mathrm{m}$.y. (Ingle, Suyehiro, von Breymann, et al., 1990), we can show that

$$
4 k_{m} D_{s}>>6 \times 10^{-14} \mathrm{~cm}^{2} / \mathrm{s}^{2}>>1.5 \times 10^{-17} \mathrm{~cm}^{2} / \mathrm{s}^{2}>>W^{2},
$$

satisfying the condition required to simplify equation 4 . 


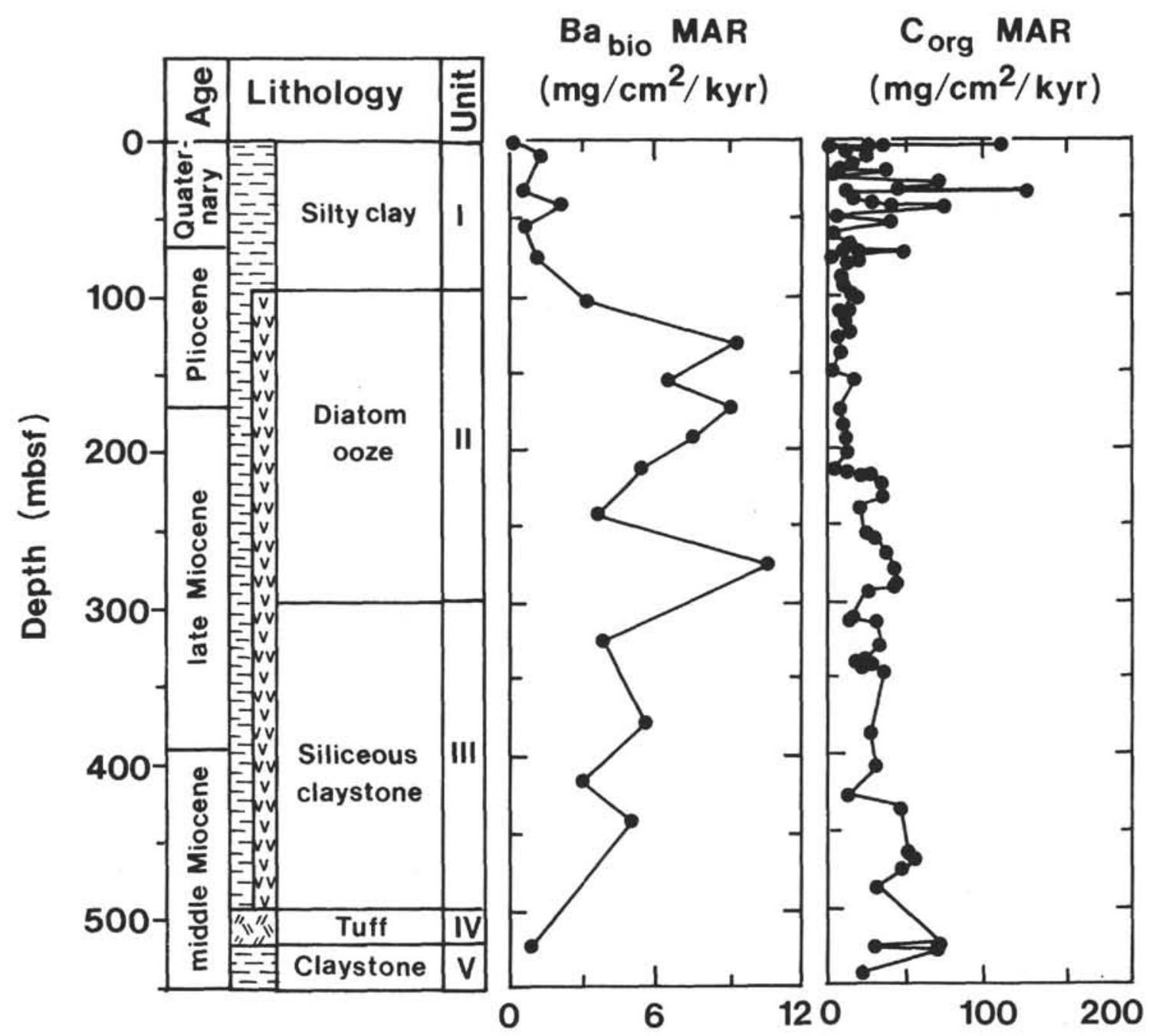

Figure 8. Accumulation of biogenic barium and organic carbon at Site 794. The lithologic column (from Tamaki, Pisciotto, Allan, et al., 1990) illustrates the increase in diatomaceous components during the high-productivity interval between 100 and 400 mbsf. The high accumulation rates of carbon in the Quaternary and middle Miocene sequences are thought to represent a terrestrial source (Tamaki, Pisciotto, Allan, et al., 1990); this interval is characterized by the deposition of siliciclastic turbidites.

\section{Diagenetic Barite}

As indicated previously, barite precipitation is thought occur in that section of the sediments where there is sufficient sulfate to cause supersaturation of this mineral. Authigenic precipitation in "barite fronts" near the end of the sulfate reduction zone has been inferred based on the barium distributions in sediments and pore fluids (Brumsack, 1986; von Breymann et al., 1990b). At Site 799 we identified a layer of barite crystals (Fig. 12) which may correspond to an authigenic precipitate in a "barite front." This layer has a light green color and a fine and smooth appearance. SEM analysis of Sample 128-799B-36X-5, 23-26 cm (323.2 mbsf), revealed the presence of barite crystals 3 to $6 \mathrm{~mm}$ in length (Fig. 13). X-ray diffractograms indicate that barite is the main crystalline phase in this layer.

Precipitation of barite at Sites 798 and 799 occurs by upward diffusion of barium and downward sulfate diffusion. Sulfate fractionation during bacterial decomposition of organic matter results in a dissolved sulfate reservoir enriched in the heavy ${ }^{34} \mathrm{~S}$ isotope (Goldhaber and Kaplan, 1980), so the authigenic barites should be isotopically heavy relative to crystals formed in modern seawater.
Sakai (1971) reported the presence of barite concretions enriched in ${ }^{34} \mathrm{~S}$ in sediments from banks in the Japan Sea. We postulate that the mechanism for barite remobilization during diagenesis in sulfate-depleted environments is indeed the mechanism leading to the formation of the deposits reported by Sakai (1971).

\section{SUMMARY}

The barium distribution in the Japan Sea drill sites permits a good overview of the geochemical behavior of this element as it pertains paleoproductivity reconstructions, diagenetic remobilization and barite precipitation in authigenic barite fronts (Fig. 14). The simultaneous uptake of barium by settling particles, coupled with the decomposition of organic matter during transport through the water column, results in an enhanced $\mathrm{C}_{\mathrm{org}} / \mathrm{Ba}$ ratio at Site $798(903 \mathrm{mbsl})$ relative to the sites drilled at greater water depths.

The rate of sediment accumulation has a twofold effect on the barium distributions. First, the degree of preservation of the barium rain seems to be a function of sediment-accumulation rates (Dymond et al., in press). Second, higher sedimentation rates result in more rapid 

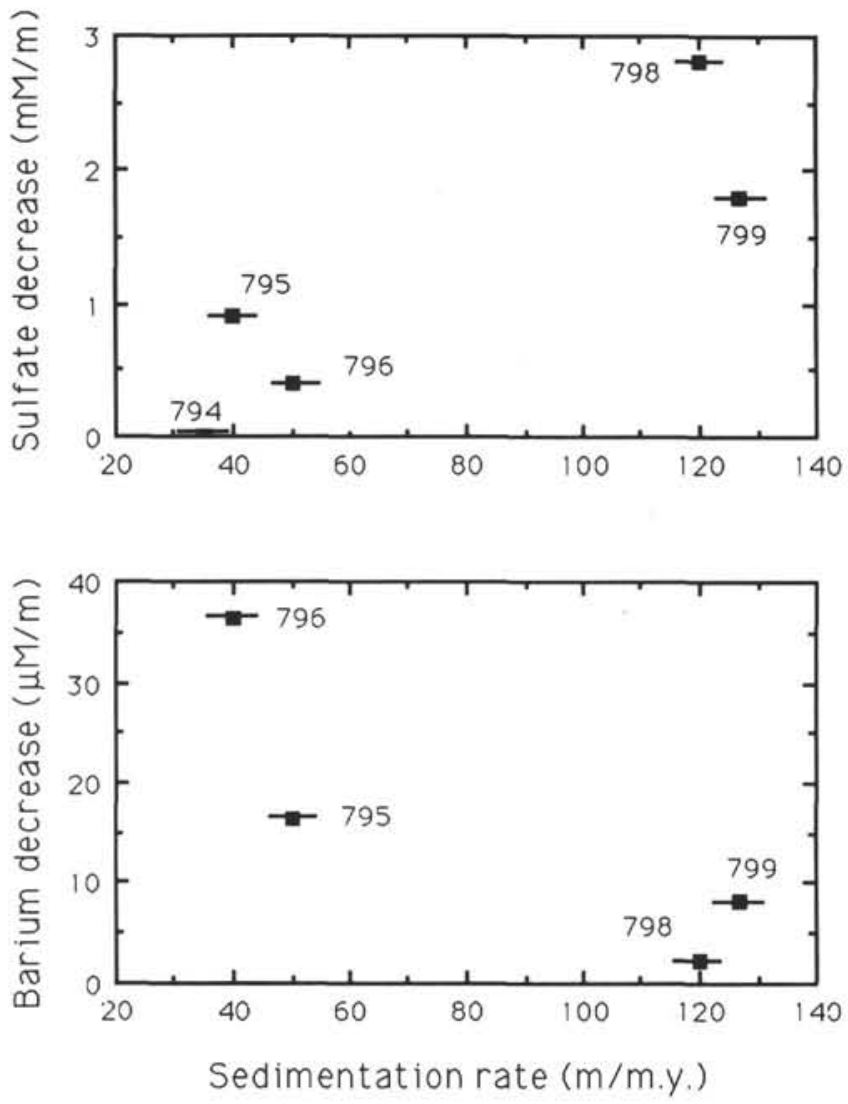

Figure 9. Dissolved interstitial sulfate gradients vs. bulk sedimentation rates from the sites drilled in the Japan Sea (upper). This empirical relationship, described by Berner (1980), illustrates the influence of sedimentation rate on the preservation of organic matter. Dissolved interstitial barium gradients vs. bulk sedimentation rates for the sites where sulfate is depleted in the pore fluids (Sites 795, 796,798, and 799) (lower). Note that the dissolved barium gradients in these sites do not correspond to the sulfate gradients; rather, the higher values are observed at the sites with slower rates of sedimentation.
Table 4. Estimated organic carbon to biogenic-barium ratios.

\begin{tabular}{ccccc}
\hline Site & $\begin{array}{c}\text { Water depth } \\
(\mathrm{m})\end{array}$ & $\begin{array}{c}\text { MAR average } \\
\left(\mathrm{g} / \mathrm{cm}^{2} / 1000 \mathrm{yr}\right)\end{array}$ & $\left(\mathrm{C}_{\text {org }} / \mathrm{Ba}\right)_{\text {rain }}{ }^{a}$ & $\left(\mathrm{C}_{\text {org }} / \mathrm{Ba}\right)_{\text {buried }}{ }^{\mathrm{b}}$ \\
\hline 794 & 2850 & 4 & $25-34$ & 11 \\
795 & 3300 & 7 & $23-34$ & 10 \\
796 & 2571 & 5 & $28-39$ & 12 \\
798 & 903 & 6 & $64-74$ & 30 \\
799 & 2084 & 4 & $33-45$ & 16 \\
\hline
\end{tabular}

aEstimated using alogarithms obtained from sediment-trap deployments in the equatorial Pacific, from Dymond et al. (in press).

${ }^{b}$ Ratio includes a correction for the different preservation of these parameters as a function of sediment-accumulation rates. $\left(\mathrm{C}_{\mathrm{org}} / \mathrm{Ba}\right)_{\text {buried }}$ values were estimated assuming $20 \%$ preservation of the organic carbon (from Dymond and Lyle, 1990 ) and 55\% preservation for barium (Dymond et al., in press).

burial and better preservation of metabolizable organic compounds, enabling these organic substances to reach the sulfate reduction zone (Berner, 1980; Reimers and Suess, 1981). Sulfate consumption in turn promotes dissolution of biogenic barite, as indicated by high levels of dissolved barium in the pore fluids. Upward diffusion of dissolved barium results in local barite precipitation near the termination of the sulfate reduction zone, as illustrated in Figure 15.

Results from sediment fluxes of particulate barium indicate that this element may be useful as a proxy indicator for ocean fertility (Dymond et al., in press). The barium distribution at Site 794 appears to reflect high levels of primary productivity in the Japan Sea from the late Miocene to the Pliocene. The high rate of barium accumulation corresponds to the widespread deposition of diatom-rich sediments, indicative of high productivity during this time. Quaternary eustatic variations in sea level, in concert with tectonically emplaced shallow sills, resulted in the topographic isolation of the sea, a condition that is in part responsible for the lower productivity of the modern Japan Sea. The present deep-water formation in the northern reaches of the basin leads to a homogenous well-oxygenated basin, a setting that is very different from the upwelling regime that resulted in a high-productivity environment from the late Miocene to Pliocene times.

The enhanced accumulation of biogenic barium in sediments of late Miocene to Pliocene age at Sites 794, 798 and 799 is illustrated in Figure 16. We have shown that barium remobilization and barite precipi-


Figure 10. Comparison of the estimated ion activity product (IAP) for barite (squares) with the value for the solubility constant at $25^{\circ} \mathrm{C}$ and 300 atm (indicated by arrows). The dissolved barium concentration is shown for comparison (line without symbols). 
tation at Site 799 results in samples highly enriched in barium relative to sediments at Site 794 , as illustrated by the solid symbols in Figure 16. If we ignore samples that lie within these barite-foci we can see a good correspondence in the accumulation rates of biogenic barium at both Sites 799 and 794. At Site 798 the sediment sequence recovered was much younger than that at Sites 794 and 799; however, the general distribution indicate a similar behavior in the barium accumulation. These observations indicate that even though diagenetic remobilization does alter the original barium signal, this element may still be useful for paleoproductivity reconstructions as long as care is taken in interpreting the barium record in environments depleted of sulfate.

\section{ACKNOWLEDGMENTS}

We are very thankful to A. Pouclet for the identification of the barite layer found at Site 799, as well as for the XRF and SEM analysis of this mineral. In addition we acknowledge the scientific, technical and crew members of ODP Legs 127 and 128 for their helpful assistance during both cruises. Financial funding was provided by grants from the JOI/USSAC support program to M. T. von Breymann and from the German ODP/SPP (German Science Foundation) to H. J. Brumsack.

\section{REFERENCES}

Adams, J., 1990. Paleoseismicity of the Cascadia subduction zone: evidence from turbidites off the Oregon-Washington margin. Tectonics, 9:569-583.

Berner, R. A., 1980. Early Diagenesis: A Theoretical Approach: Princeton (Princeton Univ. Press).

Bishop, J. K., 1988. The barite-opal-organic carbon association in oceanic particulate matter. Nature, 24:341-434.

Brumsack, H. J., 1986. The inorganic geochemistry of Cretaceous black shales (DSDP Leg 41) in comparison to modern upwelling sediments from the Gulf of California. In Summerhayes, C. P., and Shackleton, N. J. (Eds.), North Atlantic Paleoceanography. Spec. Publ.-Geol. Soc. Am., 21:447-462.

Church, T. M., and Wolgemuth, K., 1972. Marine barite saturation. Earth Planet. Sci. Lett., 15:35-44.

Dymond, J., 1981. Geochemistry of Nazca plate surface sediments: an evaluation of hydrothermal, biogenic, detrital and hydrogenous sources. In Kulm, L. D., Dymond, J., Dash, E. J., and Hussong, D. M. (Eds.), Nazca Plate: Crustal Formation and Andean Convergence. Mem.-Geol. Soc. Am., 154:33-174.

Dymond, J., and Lyle, M., in press. Particle fluxes in the ocean and implications for sources and preservation of ocean sediments. In Hay, W. W. (Ed.) Geomaterial Fluxes, Glacial to Recent. Nat. Res. Counc., Washington, D.C. (Nat. Acad. Sci. Press).

Dymond, J., Lyle, M., Finney, B., Piper, D. Z., Murphy, K., Conard, R., and Pisias, N., 1984. Ferromanganese nodules from MANOP Sites H, S, and $\mathrm{R}$ : control of mineralogical and chemical composition by multiple accretionary processes. Geochim. Cosmochim. Acta, 48:931-949

Dymond, J., Suess, E., and Lyle, M., in press. Barium in deep sea sediment: a geochemical indicator of paleoproductivity. Paleoceanography.

GEOSECS, 1987. Atlantic, Pacific and Indian Ocean Expeditions. Shorebased Data and Graphics (Vol 7). Nat. Sci. Found., Washington, D.C.

Gieskes, J. M., and Peretsman, G., 1986. Water chemistry procedures aboard JOIDES Resolution - some comments. ODP Tech. Note, 5.

Goldberg, E. D., and Arrhenius, G.O.S., 1958. Chemistry of Pacific pelagic sediments. Geochim. Cosmochim. Acta, 13:153-212.

Goldhaber, M. B., and Kaplan, 1. R., 1980. Mechanisms of sulfur incorporation and isotope fractionation during early diagenesis in sediments of the Gulf of California. Mar. Chem., 9:95-143.

Gurvich, Y. G., Bogdanov, Y. A., and Lisitzin, A. P., 1978. Behavior of barium in Recent sedimentation in the Pacific. Geokhim., 3:359-374. (In Russian)

Iijima, A., Tada, R., and Watanabe, Y., 1988. Developments of Neogene sedimentary basins in the northeastern Honshu arc with emphasis on Miocene siliceous deposits. J. Fac. Sci., Univ. Tokyo, 21:417-466.
Ikebe, Y., and Maiya, S., 1981. Akita and Niigata areas. In Tsuchi, R. (Ed.), Neogene of Japan-Its Biostratigraphy and Chronology: Shizuoka (Kurofume Printing), 68-75

Ingle, J. C., Jr., 1975a. Pleistocene and Pliocene planktonic foraminifera from the Sea of Japan, Leg 31, Deep Sea Drilling Project. In Karig, D. E., Ingle, J. C., Jr., et al., Init. Repts. DSDP, 31: Washington (U.S. Govt. Printing Office), 693-702.

- 1975b. Summary of late Paleogene-Neogene stratigraphy, paleobathymetry, and correlations, Philippine Sea and Sea of Japan region. In Karig, D. E., Ingle, J. C., Jr., et al., Init. Repts. DSDP, 31: Washington (U.S. Govt. Printing Office), 837-855.

Ingle, J. C., Jr., Suyehiro, K., von Breymann, M. T., et al., 1990. Proc. ODP, Init. Repts., 128: College Station, TX (Ocean Drilling Program).

Jumars, P. A., Altenbach, A. V., de Lange, G. J., Emerson, S. R., Hargrave, B. T., Muller, P. J., Prahl, F. G., Reimers, C. E., Steiger, T., and Suess, E., 1989. Transformation of seafloor arriving fluxes into the sedimentary record. In Berger, W. H., Smetaceck, V., and Wefer, G. (Eds.), Productivity of the Ocean: Present and Past. Dahlem Workshop, Life Sci. Res. Rep., 44:291-311.

Lea, D. W., and Boyle, E. A., 1989. Barium content of benthic foraminifera controlled by bottom water composition. Nature, 338:751-753.

Leinen, M., and Pisias, N., 1984. An objective technique for determining end-member compositions and for partitioning sediments according to their sources. Geochim. Cosmochim. Acta, 48:47-62.

Li, Y. H., and Gregory, S., 1974. Diffusion of ions in seawater and in deep-sea sediments. Geochim. Cosmochim. Acta, 38:703-714.

Matoba, Y., 1984. Paleoenvironment of the Sea of Japan. Benthos '83: Pau (Elf Aquitaine), 409-414.

Owen, B. B., and Brinkley, S. R., 1941. Calculation of the effect of pressure upon ionic equilibria in pure water and in salt solution. Chem. Rev., 29:461-464.

Prahl, F. G., and Muehlhausen, L. A., 1989. Lipid biomarkers as geochemical tools for paleoceanographic study. In Berger, W. H., Smetaceck, V., and Wefer, G. (Eds.), Productivity of the Ocean: Present and Past. Dahlem Workshop, Life Sci. Res. Rep., 44:271-289.

Reimers, C. E., and Suess, E., 1981. Spatial and temporal patterns of organic matter accumulation on the Peru continental margin. In Thiede, J., and Suess, E. (Eds.), Coastal Upwelling (Pt. B): New York (Plenum), 311-346.

Rösler, H. J., and Lange, H., 1972. Geochemical Tables: Amsterdam (Elsevier). Sakai, H., 1971. Sulfur and oxygen isotopic study of barite concretions from banks in the Japan Sea off Northeast Honshu. Geochem. J., 5:79-93.

Schmitz, B., 1987. Barium, equatorial high productivity and the northward wandering of the Indian continent. Paleoceanography, 2:63-77.

Shimmield, G. B., and Mowbray, S. R., 1991. The inorganic geochemical record of the northwest Arabian Sea: a history of productivity variation over the last 400 k.y. from Sites 722 and 724. In Prell, W. L., Niitsuma, N., et al., Proc. ODP, Sci. Results, 117: College Station, TX (Ocean Drilling Program), 409-430.

Takayasu, T., and Matoba, Y. (Eds.), 1976. Guidebook for Excursion 1. Oga Peninsula. First Int. Congr. Pacific Neogene Stratigr., Shizuoka (Kurofune Print Co.).

Tamaki, K., Pisciotto, K., Allan, J., et al., 1990. Proc. ODP, Init. Repts., 127: College Station, TX (Ocean Drilling Program).

Taylor, S. R., 1964. Abundance of chemical elements in the continental crust: a new table. Geochem. Cosmochim. Acta, 28:1273-1285.

von Breymann, M. T., Collier, R., and Suess, E., 1990. Magnesium adsorption and ion exchange in marine sediments: a multicomponent model. Geochim. Cosmochim. Acta, 54:3295-3313.

von Breymann, M. T., Emeis, K. C., and Camerlenghi, A., 1990. Geochemistry of sediments from the Peru upwelling area: results from Sites 680,685 and 688. In Suess, E., von Huene, R., et al., Proc. ODP, Sci. Results, 112: College Station, TX (Ocean Drilling Program), 491-504.

von Breymann, M. T., Emeis, K. C., and Suess, E., in press. Water-depth and diagenetic constraints in the use of barium as a paleoproductivity indicator. In Summerhayes, C. P., Prell, W., and Emeis, K. C. (Eds.), Evolution of Upwelling Systems Since the Early Miocene. Geol. Soc London.

Weedon, G. P., and Shimmield, G. B., 1991. Late Pleistocene upwelling and productivity variations in the northwest Indian Ocean deduced from spec- 
tral analysis of geochemical data from Sites 722 and 724. In Prell, W. L., Niitsuma, N., et al., Proc. ODP, Sci. Results, 117: College Station, TX (Ocean Drilling Program), 431-444.

Westall, J. C., Zachary J. L., and Morel, F.M.M., 1987. MINEQL. A computer program for the calculation of chemical equilibrium composition of aqueous systems. Dept. of Chem., Oregon State Univ., Rep. 86-01.

Worthington, L. V., 1981. The water masses of the World Ocean: some results of a fine-scale census. In Warren, B. A., and Wunsch, C. (Eds.), Evolution of Physical Oceanography: Cambridge (MIT Press), 42-69.

\section{Date of initial receipt: 26 March 1991}

Date of acceptance: 14 November 1991

\section{Ms 127/128B-168}

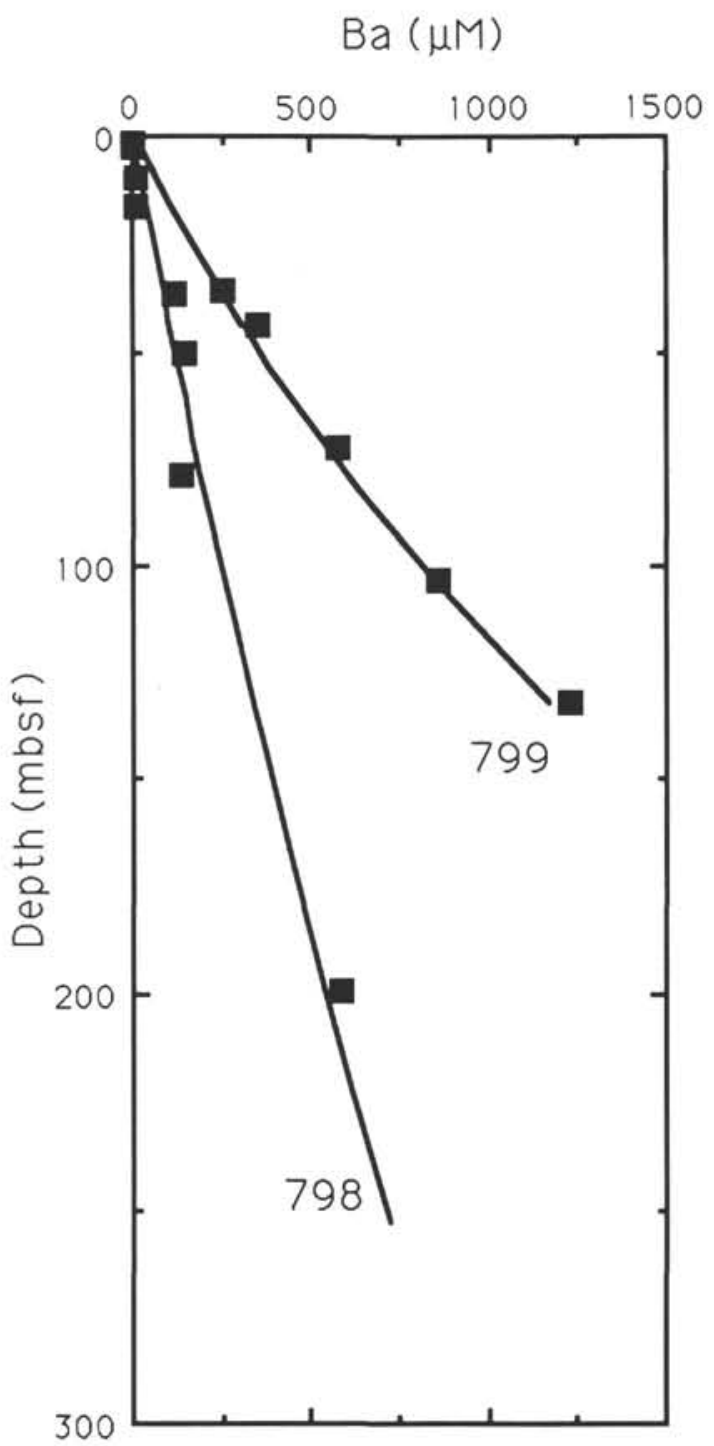

Figure 11. Dissolved barium vs. depth for samples above barite saturation depths at Sites 798 and 799 (squares). Solid lines drawn through the data are best fits to equation 5 . See text for details.

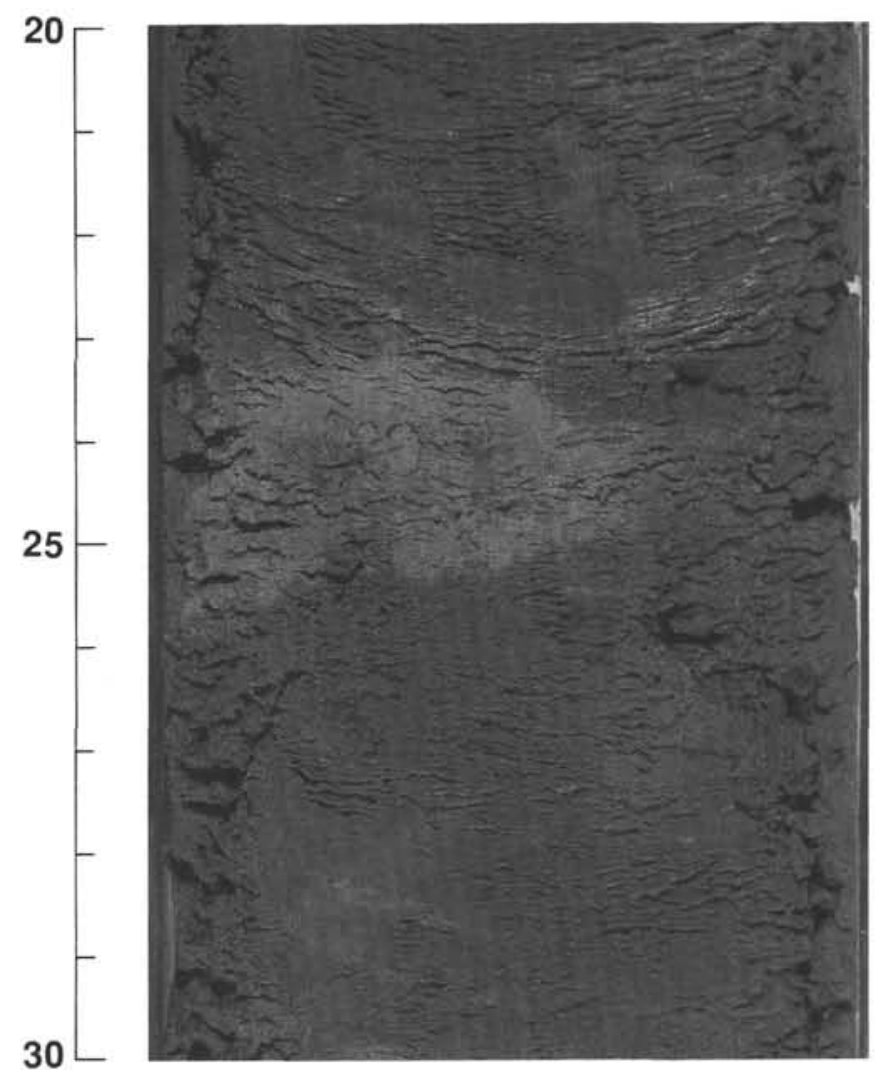

Figure 12. Core photograph of "barite front" layer in Section 128-799B-36X-5, $23-26 \mathrm{~cm}$, at $323.2 \mathrm{mbsf}$. This layer has a light green color and a smooth appearance. Barite was identified by SEM (Fig. 13) and XRF analysis. 


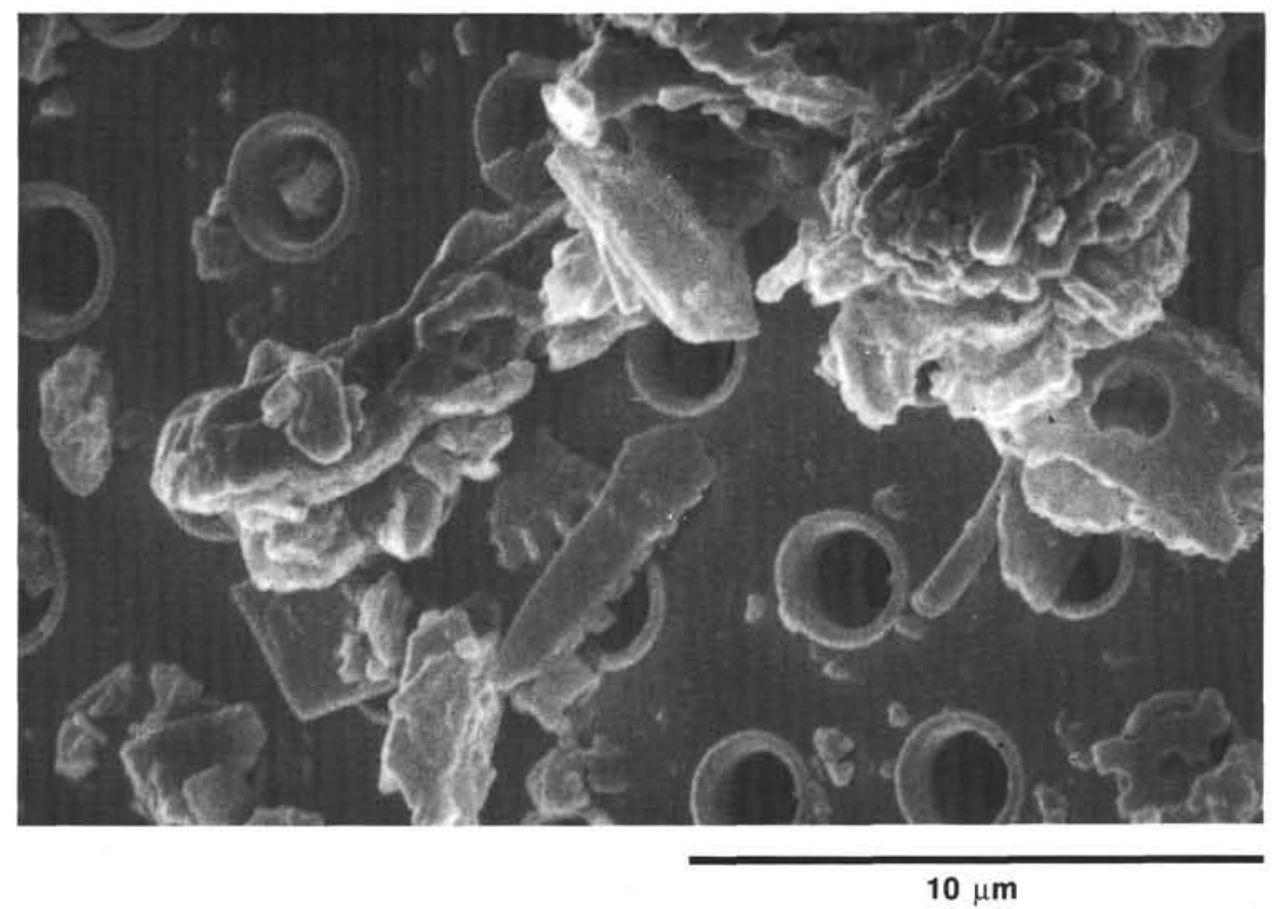

Figure 13. SEM photographs of Sample 128-799B-36X-5, 23-26 cm, indicating the presence of barite crystals.

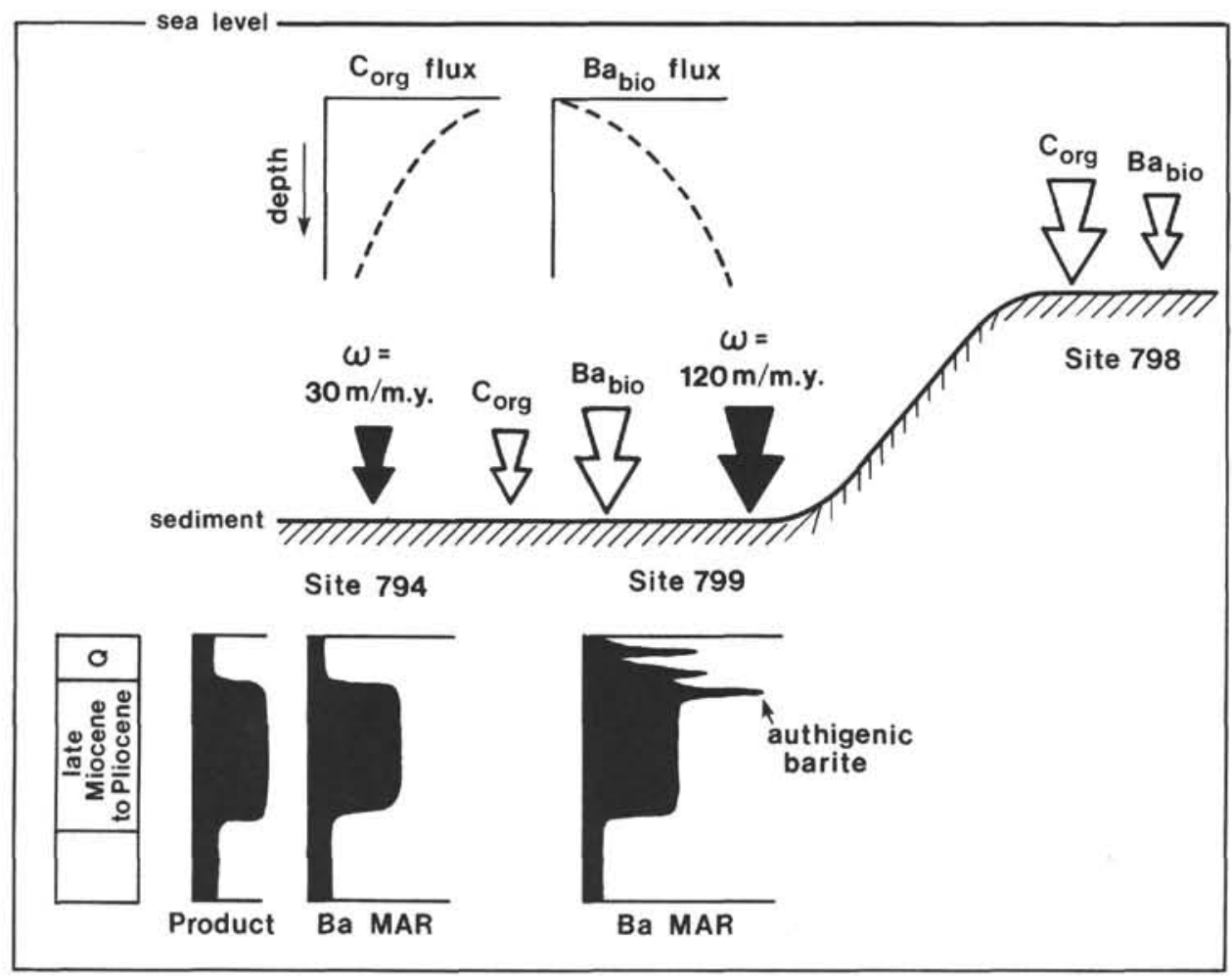

Figure 14. Schematic diagram illustrating the geochemical behavior of barium in the Japan Sea. The water column fluxes of $\mathrm{C}_{\text {org }}$ and $\mathrm{Ba}_{\text {bio }}$ are based on data of Dymond et al. (in press) and are reflected in the different $\mathrm{C}_{\text {org }} / \mathrm{Ba}_{\text {bio }}$ ratios (open arrows) between Site 798 ( $903 \mathrm{mbsf}$ ) and the sites drilled in water depths greater than $2 \mathrm{~km}$. The high rate of sedimentation at Site 799 (solid arrows) results in sulfate depletion in the pore fluids, which in turn leads to barite dissolution and reprecipitation in biogenic fronts. Sulfate is not depleted in the pore fluids at Site 794. The lack of diagenetic remobilization of biogenic barium at this site preserves the high-barium signal associated with the high-productivity sequences deposited during the late Miocene to Pliocene. 


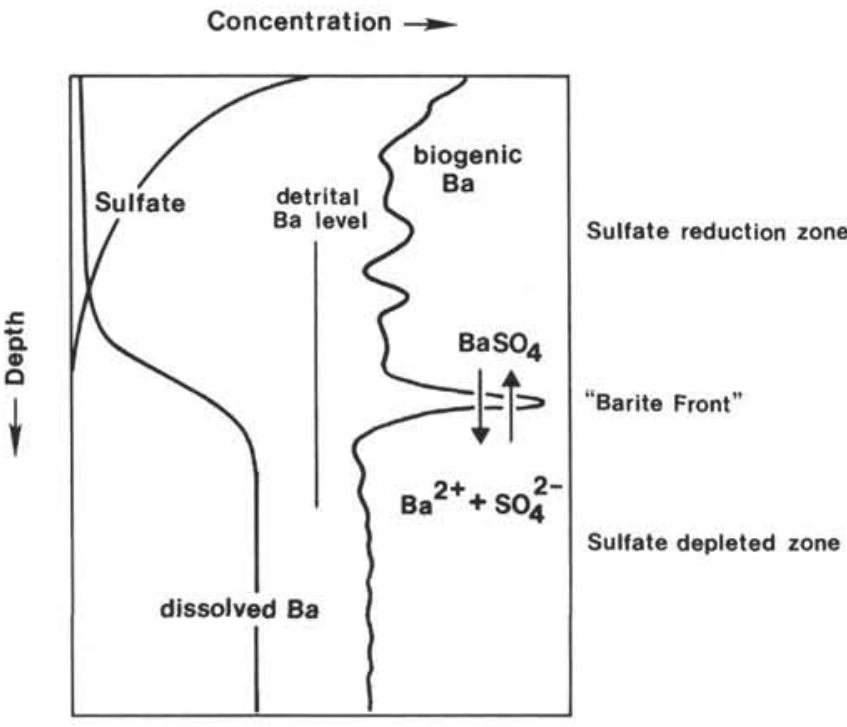

Figure 15. Schematic diagram illustrating the precipitation of authigenic barite near the zone of sulfate depletion by upward migration of dissolved barium and downward diffusion of sulfate.
A

MAR biogenic barium
$\left(\mu \mathrm{g} / \mathrm{cm}^{2} / 1000 \mathrm{yr}\right)$

B

$1000 \quad 2000$
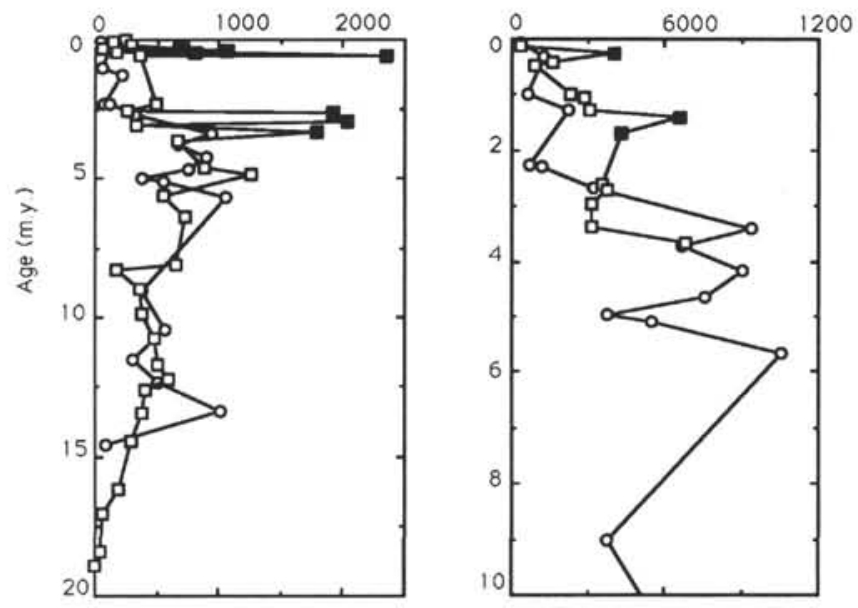

Figure 16. Mass accumulation rates (MAR) of biogenic barium vs. age (squares) at Site 799 (A) and Site 798 (B). Barium accumulation in the sediments at Site 794 is shown for comparison (open circles). The solid symbols represent samples where the high concentrations probably reflect barium remobilization and reprecipitation in authigenic barite fronts. 